


\title{
The Role of Information Technologies in Improving Efficiency of Russian Customs Administration (Based on Results of Sociological Survey)
}

\author{
DOI: https://doi.org/10.46398/cuestpol.3969.38
}

\author{
Andrey Kurochka * \\ Mikhail Popov ** \\ Inna Gaidareva *** \\ Victoria Enina $* * * *$
}

\begin{abstract}
As a research objective, the digital paradigm of economic and social development, in general, which defines the information strategy for the development of the Russian customs service and administration as necessary and priority, is analyzed. The methodological basis is based on the ideas and principles of an integrated information approach to the study of the customs service and the concept of "customs service», which treats the customs administration as service oriented. We also use additional theoretical approaches (socio-cultural and neo-institutional) as an explanatory model of the developmental characteristics of the Russian customs service. The empirical verification of conceptual attitudes in this study was conducted based on our 2020 expert sociological survey. In the survey, there were 269 employees of Rostov customs, which is structurally included in the Southern Customs Administration. The study concludes that the greater efficiency in the positive dynamics of the work of the Russian customs authorities is associated with the introduction of information technologies (especially electronic declaration). Consequently, the results of this study can be used to develop a strategy to overcome certain barriers in service.
\end{abstract}

Keywords: information technology; customs administration; customs system; customs authorities; digitization of computerization.

* Graduate Student of the Department of Theoretical Sociology and Methodology of Regional Studies, Southern Federal University, Rostov-on-Don, Russia. ORCID ID: https://orcid.org/oooo-0002-98953752. Email: kurochka-andrey@yandex.ru

** Editor-in-Chief of the Scientific Journal "Humanities, Socio-Economic and Social Sciences, Krasnodar, Russia. ORCID ID: https://orcid.org/oooo-0002-2090-0933. Email: popov-52@mail.ru

*** PhD of Social Sciences, Associate Professor of the Department of Constitutional and Administrative Law, Adygeya State University, Maykop, Russia. ORCID ID: https://orcid.org/oooo-0003-2398-7592. Email: alay_1968@mail.ru

**** PhD of Social Sciences, Associate Professor of the Department of "Automobile Transport and Technological Equipment", Don State University, Shakhty, Russia. ORCID ID: https://orcid.org/oooooo02-9116-9877. Email: kurochka-andrey@yandex.ru 
Andrey Kurochka, Mikhail Popov, Inna Gaidareva y Victoria Enina
The Role of Information Technologies in Improving Efficiency of Russian Customs Administration
616 (Based on Results of Sociological Survey)

El papel de las tecnologías de la información en la mejora de la eficiencia de la administración aduanera rusa (según los resultados de la encuesta sociológica)

\section{Resumen}

A modo de objetivo de investigación se analiza el paradigma digital del desarrollo económico y social, en general, que define la estrategia de información para el desarrollo del servicio y la administración aduanera de Rusia como necesaria y prioritaria. La base metodológica se basa en las ideas y principios de un enfoque integrado de información para el estudio del servicio aduanero y el concepto de «servicio aduanero», que trata a la administración aduanera como orientada al servicio. También utilizamos enfoques teóricos adicionales (socioculturales y neoinstitucionales) como modelo explicativo de las características de desarrollo del servicio de aduanas ruso. La verificación empírica de las actitudes conceptuales de este estudio se llevó a cabo sobre la base de nuestra encuesta sociológica de tipo experto de 2020. En la encuesta, había 269 empleados de la Aduana de Rostov, que está estructuralmente incluida en la Administración de Aduanas del Sur. El estudio concluye que la mayor eficiencia en la dinámica positiva del trabajo de las autoridades aduaneras rusas está asociada con la introducción de tecnologías de la información (especialmente con la declaración electrónica). En consecuencia, los resultados de este estudio se pueden utilizar para desarrollar una estrategia para superar ciertas barreras en el servicio.

Palabras clave: tecnologías de la información; administración aduanera; sistema aduanero; autoridades aduaneras; digitalización de la informatización.

\section{Introduction}

Strategically important areas of development of the Russian Federation include creation of favorable conditions for foreign economic activity, increasing competitiveness and improving the investment climate of the country (Anisina and Pavlova, 2021). In this regard, customs administration naturally falls into the focus of public and scientific attention. It should be noted that over the past decade a lot has been done to improve its efficiency, which has yielded positive results, especially in the field of digitalization of customs procedures (Balandina et al., 2018). Experts state that Russia is even ahead of other countries in terms of efficiency and timeliness of publishing information on classification and origin of goods, possibility and conditions for appealing administrative decisions by the regulatory authorities (Solehzoda, 2017; Dmitrieva et al., 2020). 
Nevertheless, experts state, that it has not yet been possible to overcome the significant gap between Russia and other countries in the field of customs administration, which determines the low position of Russian customs service in international rating (Koroleva et al., 2019; Kiyanova et al., 2020). The problems associated with customs clearance procedure and the significant time spent on processing documents (the number of documents being disproportionately large), have a painful impact on functioning of Russian customs system. This system has some other problems: the growth of business costs, the lack of sustainable partnership with business actors; disjointed work of customs and tax services and, as a result, the reproduction of shadow schemes and strategies, in customs payment and taxes. (Vorotyntseva et al., 2020; Dmitrieva et al., 2021).

The solution of these and other problems that determine the lag of Russian customs system from other states is directly related to high quality of customs administration. Approved by the Government of the Russian Federation in May 2020 (No. 1388-r), the "Customs Service Development Strategy until 2030" involves overcoming barriers to improve competitiveness of customs system by creating favorable conditions for all of the participants in foreign economic activity. Taking into account the world practice of customs administration (primarily related to the digital paradigm transition of customs services), it is focused on automation of business processes related to customs administration; interaction of customs authorities with other government agencies and business through electronic technologies; reducing time and financial costs for participants in foreign economic activities while improving the effectiveness of customs control (Romanovskaya et al., 2020).

Thus, although the period of Russian customs service reform has brought some positive results, the remaining problems in the system of customs administration do not yet allow us to assess it as one meeting international standards and tasks of economic development of Russia, ensuring its economic security.

This determines social significance of the study, while its scientific relevance is associated with a wide range of opinions and positions regarding the concept of customs administration, methodological models of its study and strategies for improving efficiency of Russian customs system and administration in the context of modern Russian realities and risks (Dmitrieva et al., 2020).

Many Russian scientists turn to the study of foreign experience in organizing management of the customs service. That seems justified in view of the earlier transition of some countries to advanced information technologies, awareness of the prospects of service work of customs authorities, understanding the need of a dialogue between customs services and business (Balandina et al., 2018). For Russian scientists, the 
factor of customs service proximity to business (in terms of understanding its problems and trying to solve them optimally) is also an important effectiveness indicator of the customs administration system (Solehzoda, 2017; Anisina and Pavlova, 2021).

Research shows that abroad they also discuss interaction of tax and customs departments and validity of their separate existence (Kahn et al., 2001). These aspects are included in Russian customs discourse, and in most cases, experts treat the inconsistency of tax and customs services as one of the serious reasons for the low efficiency of Russian customs administration.

At the same time, despite some discussions in the study of Russian customs administration, it is obvious to most scientists that transition to the digital paradigm of economic and social development in general determines (as necessary and priority) the information strategy for development of Russian customs service and its organizational and managerial component, i.e., customs administration. Many studies have been devoted to this aspect (Dmitrieva et al., 2021). However, there is a clear shortage of sociological works in this direction. At the same time, sociological reflection on the problems of management and managerial efficiency can lead us to a new level of understanding and solving problems related to improving efficiency of Russian customs administration.

\section{Materials and Methods}

A deep examination of the problematic background of Russian customs authorities and customs administration involves an appeal not only to statistical data, positions of scientists and analysts but the opinion of customs system employees themselves. This will allow us to look "from the inside", through the eyes of the main actors in organization of customs process and functioning of this sphere.

In this regard, sociological study of the role of information technologies in improving efficiency of Russian customs administration (which is the key goal of this work) is based on the array of our sociological survey empirical results. The full-time employees of Rostov customs presented their expert opinion on the key areas of reforming Russian customs service and meeting the international standards.

Our study was conducted in the period from April to June 2020 according to the type of expert survey based on a standardized questionnaire. In total, 269 employees of the Rostov Customs, structurally included in the Southern Customs Administration (among other 7 customs offices) took part in our expert study. The selection of experts was carried out on the 
basis of data on the total number of employees (879 people) of the Rostov Customs for the survey period, i.e., April 2020, in the ratio of management and inspection staff. The study involved 26 employees of management staff and 243 employees of inspection staff. The selection of respondents also took into account their work experience, gender and age. Among the experts there were 144 men and 125 women aged 18 to 65 years. 59 people had less than 5 years of work experience, 46 - from 5 to 10 years, 93 - from 10 to 20 years, 68 - from 20 to 30 years and 3 - over 30 years.

Methodological foundations of this study are based on a number of concepts and theoretical paradigms that are most adequate to the current trends in development of customs administration on a global scale and in the Russian state, following international standards and trends.

One of these approaches, which reflects the needs and realities of development in a modern way, is the information-integrated approach. Anisina and Pavlova (2021) state that this approach does not contradict the traditional administrative paradigm of studying the customs service, but, on the contrary, complements and forms it in a synergistic form. Within the framework of this approach, customs (as the main core of customs services formation) integrate various elements of customs service sphere and projects a kind of "informational and legal image of the service" (Anisina and Pavlova, 2021). In this conceptual design, customs appear as a "service customs", and customs administration - as a service-oriented one.

The advanced countries have recognized the advantages of the "service concept" in customs affairs and management. In fact, the world customs system can be called a system of customs service (Balandina et al., 2018), focused primarily on effective interaction with business to increase its effectiveness and ensure a high level of economic security.

This, of course, involves minimizing bureaucratic procedures of customs process and various types of costs (financial, time) for participants in foreign economic activity (FEA). Within the framework of the "service customs" concept, control, and promotion of trade (business) are considered as components of a single mechanism aimed at positivizing attitudes of business to the customs service; improving the quality of services; simplification of customs procedures for law-abiding participants of foreign trade, etc. All that determines the evolutionary trajectory of customs system development to the "service customs".

This service nature of customs, which is still quite new for the entire world community and for Russia in particular, defines provision of state (customs) services as its most important function, which does not contradict the structural and functional component of Russian customs system as a state structure designed to promote effective development of foreign trade activities in control and law enforcement activities within certain functional powers (Krasulina et al., 2019; Dmitrieva et al., 2020). 
Andrey Kurochka, Mikhail Popov, Inna Gaidareva y Victoria Enina

620

The Role of Information Technologies in Improving Efficiency of Russian Customs Administration (Based on Results of Sociological Survey)

In the outlined methodological priorities, customs administration should be considered as a management activity of customs authorities, designed to promote the development of foreign trade, and provide services to persons moving goods and vehicles across the customs border, as well as perform tax, law enforcement and control functions (Solehzoda, 2017; Dmitrieva et al., 2021).

\section{Results}

One of the problems in functioning of Russian customs service is traditionally called "administrative barriers" (Kiyanova et al., 2020) which hinder the customs formalities. The results of our expert survey have generally confirmed this well-established point of view: $54.6 \%$ of Rostov Customs employees we surveyed believe that administrative barriers, albeit slightly, hinder the customs control, 22.3\% of experts are convinced that this factor has a significant impact. At the same time, 50.2\% of experts state, that it is impossible to completely overcome administrative barriers, but it does not negate the need to fight this vice, which, from the point of view of only $12 \%$ of the experts surveyed, can be completely eradicated in customs control system. A fairly large number of experts (22.7\%) think that without administrative barriers the customs control system cannot function in principle, i.e., the barriers are generated by the very system of state administration.

Most of the customs officials still see the need to overcome administrative barriers, and, as our research has shown, the most effective way to treat them is the effective use of new information and communication technologies in activities of Russian customs authorities, such as electronic declaration, interdepartmental interaction, auto-registration of declarations for goods, auto-release of goods, etc. Among the information technologies that have been developed in administrative activities of customs authorities, electronic declaration was named the first in terms of effectiveness (4.25 points on a 5 -grade scale).

It was followed by the procedure of preliminary information (3.95 points), automatic registration of declarations for goods (3.76 points), automatic release of goods in accordance with the declared customs procedure (3.63 points). The lowest number of points $(3,59)$ in the rating table of the types of information technology used in administration of customs authorities scored a system of interdepartmental electronic cooperation (SIEC). It corresponds to the experts' opinion on measures for the most effective development of e-Declaration mechanism in Russian customs system. The majority of respondents ( 17.9 per cent) believes that it is necessary to establish the mechanism of interdepartmental interaction in practice of 
electronic communication, interaction of foreign trade participants and regulatory authorities (tax and customs) within the framework of a single information system, standardized forms of electronic communication and data exchange.

Among the significant measures there were also those related to introduction of more effective mechanisms of interaction between electronic customs and customs of control (17.7\%); maximum simplification of electronic declaration technologies (17.0\%); improvement of the mechanism for providing information to the customs authority, without the need to duplicate it (14.9\%), as well as regulatory legislation in the field of implementing the electronic declaration system in activities of Russian customs (9.6\%).

Experts also noted the importance of studying the world experience in implementation of information technologies and electronic declarations in the system of customs authorities, creation of special centers for implementation of this task (8.1\%). At the same level of significance there was the measure associated with reduction of information volume provided in declaration for goods (8.0\%), in contrast to the measures related to ensuring confidentiality and protection of information, primarily in the process of interdepartmental interaction (4.4\%), as well as the use of sociological diagnostics and forecasting methods (2.2\%). Without them it is difficult to count on effectiveness of innovations and ongoing reforms, since they should be based on real assessments of the emerging interaction system for participants in foreign economic activity and customs authorities.

Assessing the overall positive implementation of information technologies in the work of customs authorities in terms of reducing the time for customs operations (61\%), primarily due to introduction of electronic declaration mechanisms and the "single window", experts pointed to a number of factors that reduce effectiveness of this process. The most significant among them there are: imperfection of electronic technologies themselves: their complexity, bulkiness, inaccessibility for understanding and use $(22,2 \%)$; the lack of a unified information system for interactions, traders and regulatory authorities as a necessary condition of effective inter-agency cooperation in electronic communications $(15,6 \%)$; problems of funding (13,6\%); the lack of qualified personnel (12,3\%); imperfection of the legal framework for Russian customs system as a system focused on new information (e-digital) technology $(10,1 \%)$.

The introduction of information technologies in organizational and managerial activities of Russian customs bodies can help to solve another problem - the lack of trust of Russian participants in foreign economic activity to the customs authorities. 
Experts named the terrible bureaucratic red tape (35\%) as the main reason for this situation. Informatization of the customs system is designed to fight it. The solution can have a positive impact on other crisis factors of confidence in customs authorities of the Russian Federation, related to the negative image of Russian customs system (31.0\%), formed in the logic of historical trajectory of Russian state development.

The opinions of experts holding different positions on the scale of "head / inspector" are somewhat divided on this issue: managers (as the key reasons for distrust of the customs authorities of modern Russia) highlight the image of the customs service that has formed over the history of the Russian state (65.4\%) and the current economic policy of the state (65.4\%), while the inspection staff of experts put the factor of excessive bureaucratic red tape in the first place among the reasons for distrust of Russian customs system (55.6\%), and the image factor - in the second place (44.9\%) (see Figure 1).

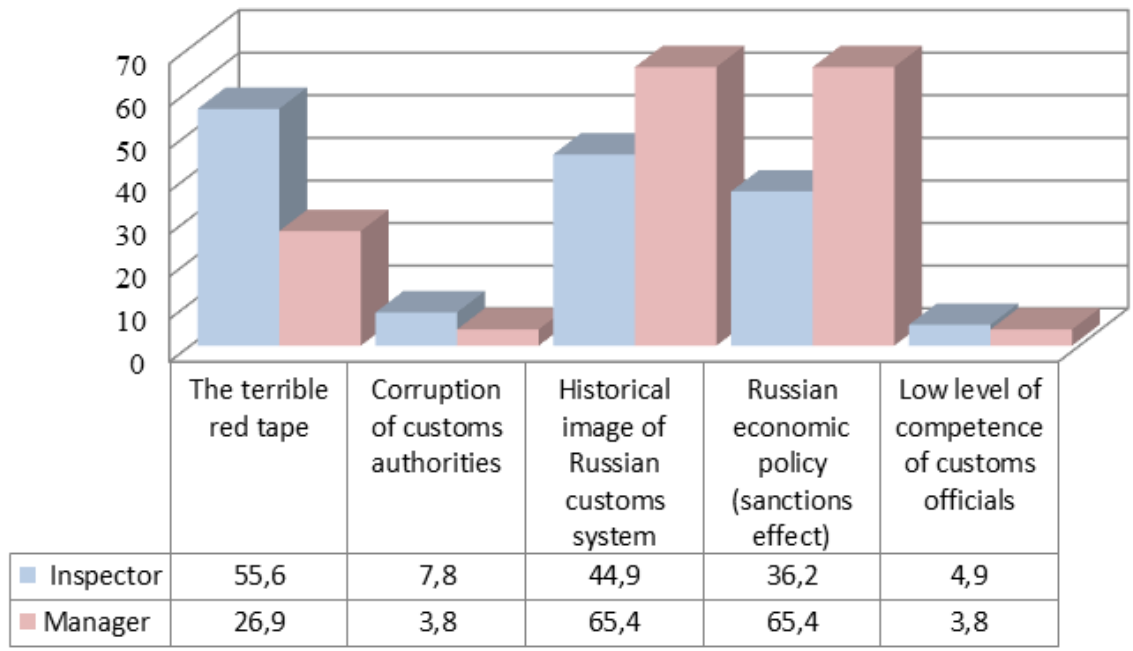

Figure 1. The Reasons for the Lack of Confidence of Foreign Trade Participants in Customs Authorities of the Russian Federation (as \%) (Kiyanova et al., 2020; Dmitrieva et al, 2021).

Figure 1 shows that experts do not associate distrust of Russian customs authorities with the low level of professionalism and corruption of customs structures. And this does not contradict positions of the experts, who do not include corruption factor in the list of key vices of Russian customs 
system. Most of the experts estimate the level of professionalism of customs employees as quite high (43.9\%), but if you look at the data on official crosssection, the situation is somewhat different: the vast majority of expert managers (50\%) rated the level of professionalism of employees as "above average" and only $23.1 \%$ of them gave the highest rating, which allows us to conclude that managers have a less high opinion of professional training and competence of their subordinates than the subordinates themselves (see Figure 2).

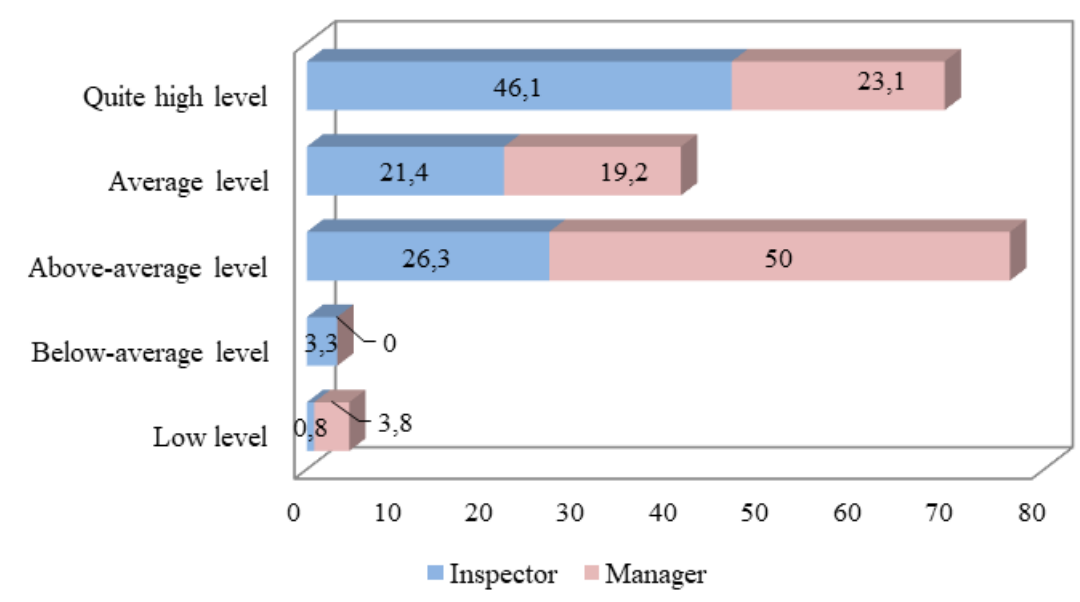

Figure 2. Assessment of Professional Level of Customs Officials, Depending on their Position (as \%) (Kiyanova et al., 2020; Dmitrieva et al, 2021).

However, we note that the managers were critical when assessing professional level of the senior staff of Russian customs authorities: $38.5 \%$ of them rated it as "above average" and only $23.1 \%$ - as "quite high". Even in this case, inspectors highly appreciated the work of customs authorities, considering in their majority (39.5\%) that professional level of managers is quite high. Although there were also quite a few who consider it to be "average" - 27.6\% (see Figure 3). 
Andrey Kurochka, Mikhail Popov, Inna Gaidareva y Victoria Enina

The Role of Information Technologies in Improving Efficiency of Russian Customs Administration (Based on Results of Sociological Survey)

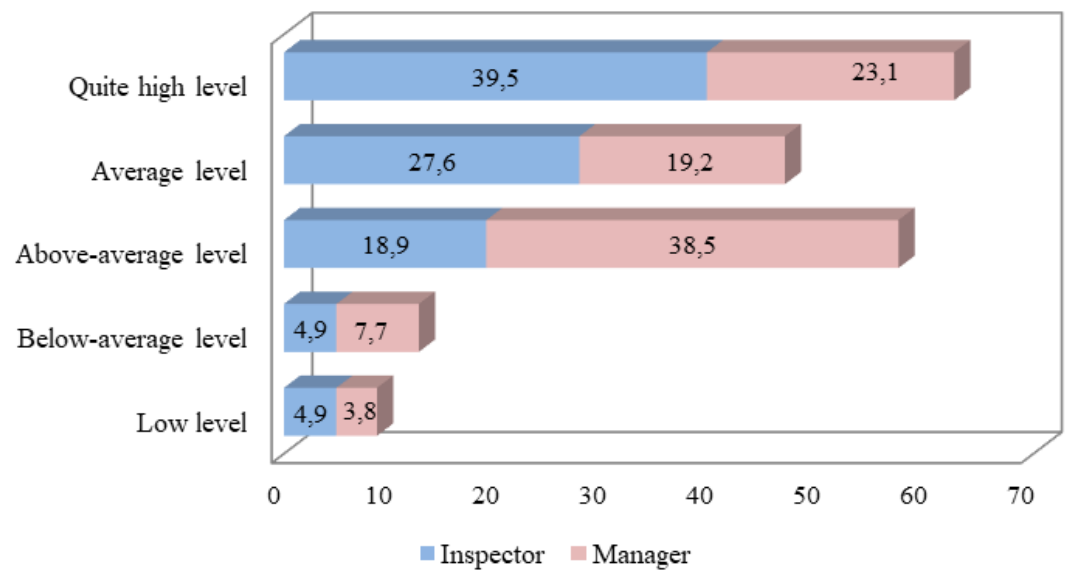

Figure 3. Assessment of Professional Level of Employees of the Customs Service Management Bodies, Depending on their Position (as \%)

(Kiyanova et al., 2020; Dmitrieva et al, 2021).

With introduction of information technologies in every sphere of activities traditionally associated with changes in the structure of organization, dynamics, productivity and quality of work, they do not bind the results of ongoing Russian customs service activities aimed at computerization of customs procedures (concentration of customs clearance in the centers of electronic declaration, differentiation of customs authorities on the powers of electronic customs and customs of actual control) with optimization of customs officials while maintaining productivity of the staff (only $11.3 \%$ of experts believe so).

Experts associate the main prospects of the measures carried out in this direction with reduction of material and time costs for customs operations prior to release of goods and reduction of the period of release of goods (29.6\%); with transition to contactless (Internet) mode of interaction between the customs authority and the citizens in the process of customs operations, making them transparent, reducing the level of corruption in Russian customs bodies $(24,4 \%)$; with the possibilities of importation of goods in a convenient location and on any temporary storage without charge to the customs authority responsible for declaring to deliver the goods from the border to the receiver, reducing the time and costs of delivery $(23,5 \%)$.

There are relatively few experts who do not associate introduction of electronic declaration mechanisms with these prospects $-11.1 \%$, but this 
percentage is not insignificant as only $32.7 \%$ of experts gave a satisfactory assessment of introducing new information technologies in their customs division, i.e. in the Rostov customs (44.6\% rated this process as "good" and only $11.2 \%$ - as "excellent").

The national nature of the problems in development of Russian customs system and customs administration has its roots in the history of Russian customs, so it is impossible not to take into account the regional peculiarities of customs authorities and services. These features also have their historical and socio-cultural conditionality, but informatization of the customs system is precisely focused on standardization, universalization of customs procedures automation and minimization of the negative impact of human factor in terms of bureaucratic effect of customs administration (a vice of Russian customs system).

\section{Discussion}

The large-scale, world-wide process of informatization of the customs (with varying intensity and efficiency in different countries) is based on the principles of the integrative (sometimes called "synergetic" or "informationintegrative") concept, which puts forward security and effective development of trade in the field of foreign economic activity as a strategic task and goal of customs administration (Dmitrieva et al., 2021). The international community has been actively using the "single window" system on the principles of this concept and in the most effective way (Balandina et al., 2018) In Russia, it has also become widespread, including in the customs sphere. The principles and mechanisms of electronic declaration are being actively implemented, but the key problem that hinders customs control and reduces effectiveness of information technologies implementation remains unaffected: the "single window" mechanism cannot ensure harmonious, holistic interaction of customs structures, services, departments and other state services and bodies. There is still a significant gap between the customs authorities and business. The partnership system of relations between them is just a projected model, transition to which is not yet possible in the current paradigm of public administration and the social order itself, which faintly resembles a democratic and socially fair one with a high culture of civic values and relations (Dmitrieva et al., 2020).

Of course, customs administration (as embedded in the system of state management of historical, political, economic, and other subjects) cannot be considered outside the socio-cultural context, even taking into account the fact that the modern digital era is rapidly changing appearance of Russian customs. In this regard, the strategy of transition of Russian customs administration to a new - digital form of work due to 
Andrey Kurochka, Mikhail Popov, Inna Gaidareva y Victoria Enina

introduction of information technologies is actively discussed in scientific and public discourse (Kiyanova et al., 2020). The high expectations and prospects associated with this transition are justified, since, as experts note, Russia has managed to make quite serious progress in improving customs administration in the course of digitalization, and this has allowed us to approach the best world examples and practices of organization and management in the field of customs relations (Balandina et al., 2018). At the same time, the remaining problems in the field of customs administration: administrative barriers, bureaucratization, corruption, etc. (Vorotyntseva et al., 2020) can be explained by the fact that modernization of Russian customs system is not systematic and comprehensive. It is one-sided, and therefore insufficiently effective, unable to resist destructive phenomena and trends of customs processes. That is why there is not solved the problem of disunity in various functions of control between the customs and tax service bodies, as well as other state bodies that also take part in customs control.

The integrative concept of customs administration suggests that transformation of the customs service institution should be determined by a complex of modernist ideas (paradigms), among which the idea of digitalization, informatization, transition to electronic mechanisms of development, artificial intelligence, hybrid systems of administration is only one of the key ones, inscribed in the logic of others, such as the idea of a process-oriented model of customs administration; the idea of managing digital (electronic) customs administration on the cognitive paradigm based on knowledge or the idea of a "service customer" (Romanovskaya et al., 2020). In Russia, such a systematic and holistic model of customs modernization is unreal, and experts see the most important cause of distrust to the customs authorities and, accordingly, the low efficiency of their activities, in he modern system of public administration. A conservative, inflexible, inherently authoritarian system of public administration, which automatically determines all the clusters of administration in the same form, determines the point nature of innovations in the field of management as well (including the customs). The system allows something, but all the other processes develop along an inertial trajectory, inscribed in institutional logic of Russian social development (Krasulina et al., 2019).

In this regard, it is understandable and predictable that development of customs administration through transition to information and digital technologies is realized in the space of many barriers: technological, administrative, economic, political, and socio-cultural (the most important ones). The latter are the most complex, because they are the most stable, weakly susceptible to rapid changes and impacts. These behavioral models are rooted in mentality of society, in its archetypes, attitudes and stereotypes. 


\section{Conclusion}

At the present stage, there is an urgent need to form a system of customs administration (adequate to international practice and international standards), which determines both the effectiveness of relations in the system of foreign economic activity, and economic well-being of Russian people, the state, and its security. The extensive customs issues discursive field of various scientific branches basically contains no disagreements about assessment of Russian customs system effectiveness and its most problematic areas. The course taken as a basis for informatization and digitalization of the customs service, implementation of measures, programs and projects related to transition to electronic mechanisms of customs services is also clearly positive, without much disagreement. This course has brought a lot of positive results, but, as the expert survey showed, many "birthmarks" of Russian customs system (bureaucratization, corruption, distrust of customs authorities, etc.) persist and are reproduced in modern social order and public administration.

In this regard, expectations for formation of Russian customs compliant with international standards as a necessary condition for reaching a competitive level of foreign economic relations with an appropriate image and level of trust may remain expectations. Implementation of this strategic task involves implementation of integrative model of modernization (reform) of Russian customs system with clear conceptual and methodological foundations of the customs administration model. The customs is a part of state administration, so its modernization should fit into the logic of state administration system modernization.

So, the customs authorities, primarily the management cluster, still face many problems, which at the present stage are mainly solved by introduction of information technologies in practice of customs control and procedures. Their effectiveness is noted by many Russian scientists, as well as by the interviewed experts (employees of the Rostov Customs). However, while we appreciate information and digital technologies in improving efficiency of customs administration, we are convinced that this strategy needs support in the form of a synergy of ideas, principles, mechanisms, and resources. In other words, they need a conceptual model of modernization (reform) of Russian customs service.

\section{Bibliographic References}

ANISINA, Karina T; PAVLOVA, Elena Y. 2021. "Policy Note: Transformation Of The Legal Mechanism OfTaxation Under The Influence Of Digitalization: Russian Case Study” In: Intertax. Vol. 49, No. 5, pp. 437 - 448. 
Andrey Kurochka, Mikhail Popov, Inna Gaidareva y Victoria Enina

628

The Role of Information Technologies in Improving Efficiency of Russian Customs Administration (Based on Results of Sociological Survey)

BALANDINA, Galina V; PONOMAREV YURIY, Yu; SINELNIKOV-MURYLEV, Sergei G; TOCHIN, Andrey V. 2018. "Customs Administration in Russia: Directions of Improvement” In: Economic Policy. Vol. 3, pp. 106-131.

DMITRIEVA, Olga A; RUDAKOVA, Elena N; MORKOVKIN, Dmitry E; GUBIN, Alexey V; PAVLOVA, Alla V; POLYAKOV, Anton E. 2020. "Recommendations About Improvement of Application of Customs Procedure of Customs Transit in the Russian Federation When Transporting Goods by the Motor Transport" In: 5th International Conference on Economics, Management, Law and Education (EMLE 2019). Atlantis Press. Vol. 12, pp. 6-11.

DMITRIEVA, Olga; RUDAKOVA, Elena; ALEXANDROVALJulia; MAJERČÁK, Peter; MAJERČ́́K, Jozef. 2021. "Customs Procedure of Customs Transit for the Carriage of Goods by Roads in Russia" In: Transportation Research Procedia. Vol. 53, pp. 204-211.

KAHN, Charles M; SILVA, Emilson CD; ZILIAK, James P. 2001. "Performancebased wages in tax collection: The Brazilian tax collection reform and its effects" In: The Economic Journal. Vol. 111, No. 468, pp. 188-205.

KIYANOVA, Liliya D; MIRONOVA, Olga A; SOKOLOVA, Eugenia M. 2020. "Ways to Improve Efficiency of Customs Payments Administration" In Proceedings of the International Conference Digital Age: Traditions, Modernity and Innovations (ICDATMI 2020). Atlantis Press. Vol. 34, No. 11, pp. 246-251.

KOROLEVA, Elena; SOKOLOV, Sergey; MAKASHINA, Irina; FILATOVA, Evgeniya. 2019. "Information technologies as a way of port activity optimization in conditions of digital economy" In: E3S Web of Conferences, EDP Sciences. Vol. 138, pp. 02002-02026.

KRASULINA, O.Y; EVCHAK, A.M; KREPKAIA, T.N; MOKHOROV, D.A. 2019. "Methodology of formation of the state financial policy in the Arctic zone of the Russian Federation" In: IOP Conference Series: Earth and Environmental Science. Vol. 302, No. 1, p. 012099. IOP Publishing.

ROMANOVSKAYA, Elena V; ANDRYASHINA, Natalia S; KUZNETSOVA, Svetlana N; SMIRNOVA, Zhanna V; IVONINA, Oksana G. 2020. "Digital Technologies in Russia: Trends, Place and Role in Economy" In: Institute of Scientific Communications Conference. Vol. 34, No. 26, pp. 344-351.

SOLEHZODA, Ayubjon. 2017. "Information technologies in the tax administration system of VAT" In: Journal of Advanced Research in Law and Economics (JARLE). Vol. 8, No. 26, pp. 1340-1344. 
VOROTYNTSEVA, Tatyana; NEMIROVA, Gulzida; VINICHENKOL, Artyom. 2020. "Problems of Application of Digital Technologies in International Trade" In: "New Silk Road: Business Cooperation and Prospective of Economic Development”. pp. 452-456. Atlantis Press. 

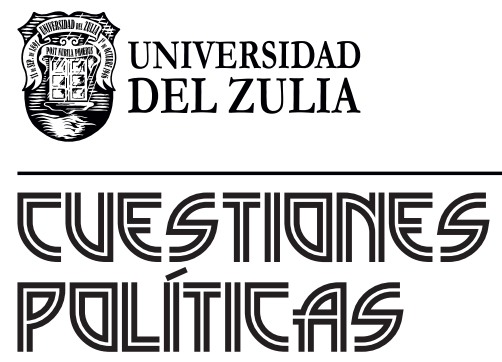

Vol.39 No 69

Esta revista fue editada en formato digital y publicada en julio de 2021, por el Fondo Editorial Serbiluz, Universidad del Zulia. Maracaibo-Venezuela 